\title{
University of Kentucky
}

From the SelectedWorks of Lisa Cliggett

1996

\section{Household Patterns of the Elderly and the Proximity of Children in a Nineteenth-Century City, Verviers, Belgium, 1831-1846}

George Alter, Indiana University Lisa Cliggett, Indiana University

Alex Urbiel, Indiana University

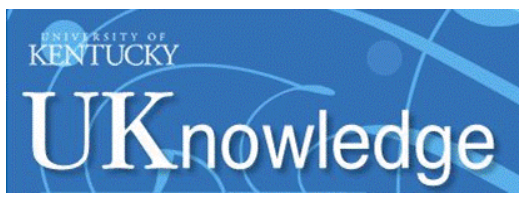




\title{
Household Patterns of the Elderly and the Proximity of Children in a Nineteenth-Century City, Verviers, Belgium, 1831-1846
}

\author{
George Alter \\ Lisa Cliggett \\ Alex Urbiel \\ Indiana University
}

\begin{abstract}
A previous generation of sociologists viewed the twentieth-century decline of household size and the growing residential isolation of the elderly with some alarm. They asked whether this represented an abandonment of the traditional European family system, in which families were assumed to have been large and extended or multigenerational. Subsequent research, however, has rejected both sides of this concern. Old people in the later twentieth century are not as isolated from their families as had been feared, and families in the past were not as large or complex as had been assumed. ${ }^{1}$ The attack on the historical component of this conventional wisdom was led by Peter Laslett. Laslett and colleagues from a number of European countries were able to show the predominance of small, nuclear family households in Western European history (Laslett, 1972). Indeed, the size and structure of households in England have been remarkably constant for at least three centuries.
\end{abstract}

Laslett's approach has been central to the historical demography of the European family for more than two decades, and it suffers from some well-known limitations. We intend not to review this entire debate here, but rather to focus on two aspects that are relevant to the study of the elderly. First, Laslett and his associates based their work on the study of the household, defined by coresidence, not on the family as defined by kinship. Clearly, kin outside the household can provide important support, and Laslett has always acknowledged this limitation. However, historical sources of information about the family are very limited, and most of this research is based upon censuses and other nominative lists. It is very difficult to reconstruct contacts with kin living outside the household.

Second, discussions of historical changes in household structure have not included a theoretical model of the position of the elderly in European history. Laslett's early work was primarily an empirical critique of prevailing sociological theories, and was not motivated by a theoretical structure of its own. Increasingly, however, Laslett has come to rely upon the concept of the "European marriage pattern" as an explanation of the predominance of the nuclear family. Recognition of a distinctive European marriage pattern began with John Hajnal's empirical finding of a West European zone of late marriage and high proportions never marrying (1965, 1983). Hajnal's explanation for this pattern describes a social system in which couples are not able to marry until they are economically independent. The younger generation must postpone marriage while they 
save toward the purchase of a farm, or wait for the older generation to pass on their inheritance. Hajnal's description of the European marriage pattern is similar in spirit to Malthus's "preventive restraint."

As a theory, the European marriage pattern does not provide an explanation of social support for the elderly. In contrast to Frederic Leplay's "stem family," or models of extended family systems that emphasize intergenerational relations, the European marriage pattern focuses attention on household formation among the younger generation. Some writers have noted the potential for intergenerational conflict in this system, where children cannot begin their own households until their parents retire or die (Shorter, 1977, pp. 32-34).

Laslett recently has argued that the European family system could not make sufficient provisions for old age and that community and state institutions were necessary to supplement it.

Retirement in the past, therefore, seems to have been secured by a miscellany of expedients rather than by a set of recognized usages and institutions.... The general conclusion to be drawn is that the coresidential family group is very difficult to adapt to the eventualities of the individual life course, and providing for old age seems to be beyond its capacities; (Laslett, 1991, p. 125)

For this reason, Laslett argues that old age security could not have been a significant factor in maintaining the high birth rate in the past.

We suggest here an alternative view of family support for the elderly in European history, which seems to be more consistent with evidence from a nineteenth-century Belgian city. We have attempted to identify and locate noncoresident children of elderly persons, so that we can describe their household patterns as choices. This addition helps to overcome an important weakness of most earlier research, which is limited to the coresident group. Our data suggest that coresidence with children was a very important source of support for the elderly, but that most of that support came from unmarried children.

Our emphasis on the importance of support from children does not run counter to the main lines of research on role of marriage in the history of European household structure. On the contrary, we propose a different perspective on the European marriage pattern, which emphasizes the advantages for parents of children's marrying late. In the next section we attempt to view the European marriage pattern from the perspective of the elderly, and conclude that parents gained substantial economic advantages from keeping unmarried children in their households. The system did result in a large number of unmarried persons without children to rely upon, but old age security was greatly enhanced for those who did marry by having a large family. 


\section{Late Marriage and the Economic Position Elderly Parents}

Although the European marriage pattern usually is presented in terms of economic circumstances effect on household formation among the younger generation, it is useful to consider their effect on the parental generation. Late marriage and high proportions never marrying created a large pool of unmarried children who were available to support elderly parents.

Studies of nineteenth-century family budget surveys emphasize the importance of children's income in the nineteenth-century. An 1853 survey of Belgian families with four children estimated that $22 \%$ of total family income came from the earnings of children (Alter, 1984). The importance of children's earnings is also apparent in the multinational family budget survey conducted by the U.S. Commissioner of Labor in 1889-90 (see Haines, 1979). Income from children was much greater than the wage earnings of wives, who could only work part-time and who generally seem to have withdrawn from the labor force in the last half of the nineteenth-century (Alter, 1984).

The contributions of children were especially important in later stages of the family life cycle because they compensated for the early decline of earnings by adult males. The peak in the age-earnings profiles of U.S. workers in the 1889-90 U.S. Commissioner of Labor survey occurred as young as 32 in some industries and usually before age 40 (Rotella \& Alter, 1990). Leboutte (1990) showed similar patterns for Belgian mine workers, whether they worked below ground or on the surface. However, total family incomes did not decline in the households of older workers. The additional income contributed by children more than compensated for the lower earnings potential of male heads of household (Haines, 1979; Rotella \& Alter, 1990). Children usually entered the labor force between ages 12 and 14 , and wage rates rose rapidly with age.

Total family incomes were highest when the head of household was age 50 to 60 and several unmarried, adult children were contributing wages. It is likely that most, if not all, of the earnings of children were pooled for the benefit of the family as a whole. Young children often worked as assistants to their parents or other kin (Smelser, 1959, pp. 187-193). In the early nineteenth-century, workers were often paid as teams, usually on a piece rate, and fathers were frequently in a position to collect the wages of adult sons and daughters. As their children entered the labor force, parents could expect to be relatively prosperous until their children went off to form their own households. A representative of the Société de Saint Francois Régis of Verviers, an organization established to combat illegitimacy by encouraging marriages, told a Belgian commission in 1886: "In the working class, often egoism, the desire to conserve the earnings of children, prevents parents from consenting to the marriage of their children" (Belgium, Commission du travail, 1887, Vol. 1 , p. 1024).

Just as reliance upon children could offset the reduced earning power of the male head of household, it could also serve as a strategy for support in old age. In a population with an average age at marriage above age 25 , and between 10 and $20 \%$ never marrying, most parents could count on having at least one unmarried child after they had passed age 65 .

This reasoning suggests a logic linking high fertility with support in old age that differs 
from the usual account. It draws attention to the benefits from never-marrying children, rather than the average returns from all children, and to the timing of children during the parents' life course. Under this strategy, parents did not count on old age support from all of their children, but they did hope to have at least one child who would take care of them. Economic transfers from most children may have been small or zero, as long as substantial support came from this caregiver. In a large family there was a greater likelihood that at least one child would never marry and be available for this role.

The timing of the first and last child played a particularly important role in the income stream of the parents. Couples preferred to have at least one child before the husband reached age 30 , so that this child entered the labor force when the husband's income was beginning to decline. They also wanted the last child to be born as late as possible, so that this child's contribution would continue into their old age. It is possible to incorporate the timing of grandchildren into this strategy as well. As the parent passed age 70 , the first set of grandchildren entered the labor force. At this point the oldest children in the middle generation were experiencing their highest total family incomes, and they were in a better position to share the burden of an elderly parent with their younger siblings.

In this model, high fertility was encouraged by two aspects that are unique to highparity births. First, high-parity births occurred at older parental ages, and high-parity children contributed to the parental household when parents needed them most. Second, high-parity births occurred at a point in the family life cycle when total family income was highest, because their older siblings were already in the labor force. Thus, parents could use the earnings of early children to finance the births of later children, and the earnings of later children to finance their own old age.

\section{Data from Nineteenth-Century Verviers}

An unusual set of documents allows us to study the details of household structure and dynamics in Verviers, Belgium. From 1806 to 1846, city officials compiled a nominative list of the population every year. These Relevés des habitans (Inventories of inhabitants) list name, occupation, place of birth, and marital status, as well as place of origin and date of arrival for those not born in Verviers. Children under age 12 are not listed by name, but are tallied with their parents. Periodically, the registers were indexed by name, and after 1828 many marginal notes were added to show deaths, out-migration, and locations in preceding and following registers. The registers refer to the population at the beginning of the year; however, internal evidence suggests that they usually took one or two months to compile. The Relevés des habitans are very similar to annual censuses, but the crossreferences to adjacent years add a continuity over time similar to population registers. In 1846 , Verviers began using continuous population registers, which were introduced throughout Belgium in that year (Alter, 1988).

Verviers has several advantages as a site for such a study. During the eighteenth century the city had become a major center for the production of woollen textiles. In early years this industry was organized along classic "protoindustrial" lines. Most of the 
spinning and weaving took place in peasant cottages in the surrounding rural areas, and finishing operations were performed in water-powered mills in the city. Verviers was the first place on the European continent to employ mechanical spinning machinery, and after 1800 the industry was rapidly transformed by steam-powered factories. In the first half of the nineteenth-century, both spinning and weaving operations were being drawn from the countryside into the city. Although most weaving was still done by hand, but it was increasingly organized into large workshops and factories (Lebrun, 1948; Desama, 1985; Gutmann, 1988).

Although it had a distinctly urban character, Verviers remained a small city, which makes it much easier to study. Between 1831 and 1846 the population rose from 18,834 to 23,339 , and peaked around 45,000 later in the century. It would be much more difficult to trace individuals in a larger city. In addition, the economies in all textile cities present certain common features, such as a predominance of female workers, that are familiar from previous studies in other places (Anderson, 1971; Tilly, 1979; Hareven, 1982).

We drew data on the elderly in Verviers from the annual registers in both cross-section and longitudinal samples. We constructed a cross-sectional view of 1831 by selecting all households that included a person age 55 or older in that year. We then constructed a longitudinal sample by focusing on persons who were 60 to 65 in 1831 . These individuals were followed forward in time through successive registers to 1846 . Thus, the longitudinal sample consists of up to 16 observations on each individual. However, attrition from mortality, migration, and recording problems in the register reduces this sample from 661 individuals in 1831 to 87 in 1846 . For each year of observation, we collected information on the entire household in which the sample person resides.

The rich documentation available in the annual registers for Verviers has enabled us to extend our view of residential choices to include kin living in different households. We have attempted to identify all of the children of our sample individuals and to locate those children who were living in Verviers. Children who were coresiding with a person in the longitudinal sample were followed when they left the parental household. We also traced our sample backward in time to the register for 1821 to identify children who had left home before 1831. We have added information about the households of noncoresident children to the data base. We have also constructed map coordinates for all of the houses in the city, so that we can calculate the physical distance between these children and their parents.

The high rate of attrition in a longitudinal sample, especially one focused on the elderly, raises a difficult question about counting the multiple observations on each individuals. If each observation is weighted equally, a person who was located in every year from 1831 to 1846 will be counted 16 times more often than one who died in 1831 . Household structure changes very slowly, however, and multiple observations of the same individual cannot be considered independent. One approach is to weight individuals inversely to the number of times that they are observed. These weights can be constructed so that each individual will be counted equally. Unfortunately, this kind of weighting has the effect of emphasizing data from younger ages. Since attrition occurs as the sample moves forward in time, individuals who leave the sample are observed at younger ages only. An 
alternative approach would attach higher weights to older ages to compensate for attrition.

We have attempted to steer a course between the dangers of giving too much weight to individuals who are observed more often, on one hand, and overweighting the younger ages, on the other. The observations on each individual were grouped into four age groups $(60-64,65-69,70-74$, and 75 and over), and weights were assigned inversely to the number of observations in each interval of ages. Thus, if an individual is observed twice in an age group, each observation is assigned a weight of one-half. The weights for each individual sum to one in each age group. ${ }^{2}$ The unweighted and weighted numbers of observations in the longitudinal sample are presented in Table 1.

\section{Old Age in Verviers, 1831}

Tables 2, 3, and 4 provide an overall picture of the households of the elderly in Verviers in 1831 from the cross-sectional sample. Tables 2 and 3 show the percentages of persons who were coresiding with other types of individuals. These categories are not exclusive, so a person residing with a child might also live with other kin or nonkin. Several patterns are noteworthy in this table. First, we note that the percentages who lived alone were much lower than present patterns in developed countries. Solitary residence increased dramatically during the twentieth century (Kobrin, 1976). Most observers attribute this increase to rising incomes and the impact of pensions and social security programs. Steven Ruggles (1991), however, has recently disputed this interpretation, arguing for changes in preferences about coresidence with children.

Second, elderly males were more likely than females to live with spouses. Half of the men age 70 to 74 were still living with wives, but only one woman in four resided with her husband. This reflects the higher mortality of males, the age differences between spouses, and higher proportions of women who never married.

Third, the proportions of persons who resided with children were high, and these proportions remained high until after age 75 . Overall, more than two thirds of persons 55 or older resided with at least one child. There is no clear difference in age patterns of coresidence with children between men and women. Widows, however, were more likely than widowers to reside with children. At younger ages coresident children are mostly unmarried. Married children become more common at older ages, but the proportion of women who resided with married children reaches only $35 \%$ among the oldest women. There is also a strong difference between men and women in coresidence with married children. Women, especially widowed women, were the most likely to live with a married child.

Fourth, the proportion of persons who lived with nonkin increased dramatically at older ages. In part, this reflects the residents in Verviers's municipal old age home, the Hospice des vieillards, which opened in 1668 (Verviers, Le Centre Public d'Aide Sociale de Verviers, 1989). This institution accommodated about 60 persons most of whom were above age 70. However, old people who were not in the old age home also frequently lived with nonkin. In contrast, other types of kin were not very important. About $10 \%$ 
of the elderly lived with siblings or other kin, when grandchildren and sons- and daughtersin-law are excluded.

Table 4 looks at household structure in a different way. This table cross-classifies the person in the sample by relationship to head of household (head/spouse, parent, other) and by the presence of children in the household. Household headship helps to identify the direction of support in cases of coresidence with children. ${ }^{3}$ It was not unusual in Verviers for newly married couples to live with parents. This arrangement was more common when the new couple was young or had borne a child before the marriage occurred, which suggests that they were receiving assistance from their parents (Alter, 1988, pp. 131-137).

There seems to have been a strong preference among the elderly for retaining household headship. Most elderly persons, male and female, who lived with children continued to be listed as the head of household. After age 75 male and female patterns tend to diverge. The oldest women show a tendency to move into the households of married children, but this option remained uncommon for males.

\section{Household Patterns in the Longitudinal Sample}

Table 5 can be used to compare the household patterns in the longitudinal sample to those in the 1831 cross-section (Table 4 ). The two samples are very similar in the proportions of persons who headed their own households, with and without children present. Two differences appear after age 70 , however. First, persons in the longitudinal sample were less likely to live in households headed by others, primarily because few of the people in the longitudinal sample entered the old age home. We are doing a special study of the origins of persons in the old age home which may explain this difference. Second, older women were less likely to live with married children in the longitudinal sample than in the cross-section. It is possible that the cross-section includes old widows who moved into Verviers to live with children, a process that would not be captured by the longitudinal sample.

Table 6 reveals the strong effect of family size on coresidence with children. The "number of children identified" is our closest approximation to total family size. We include all children who were found in the 16 years of the longitudinal sample and in the registers of the $1820 \mathrm{~s}$. Parents with very large families were nearly assured of having at least one child to live with, and these coresident children usually were unmarried. We also see the difference between older males and females that emerged in earlier tables. Fathers and mothers with smaller families were equally likely to live with unmarried children. But mothers with one or two children were much more likely to live with married children. Among parents with only one child, mothers were $13 \%$ more likely to live with a child than fathers, because mothers were more likely to live with married children.

In Table 7 we add two other dimensions, household headship and marital status. Persons who had ever been married tended to retain household headship, and more than two thirds of currently married couples had at least one child living with them. Widows with one or two children were the only group that tended to move into the household of 
a married child. Daniel Scott Smith (1979) found similar patterns in the U.S. census of 1900 , which reports the number of surviving children. However, U.S. widows seem to have been more likely to live with married children than were widows in early nineteenthcentury Verviers. This difference may lie in the earlier marriage and higher proportions marrying in the United States.

In Table 8 we examine the spatial distances between parents and their closest child in a different household. This table considers whether parents who did not have children living in the same household were more likely to have children living nearby. In most cases, children in the "Locations unknown" category probably had migrated out of the city. Those who did live in the city were not likely to be far away. Verviers was a small place, and the greatest distance between any parent and child in the data set was only 1.2 kilometers. Nevertheless, there was a slight tendency for parents without coresident children to have children living in different households at the same address. ${ }^{4}$ Table 9 considers the choices that parents made to live among different types of children. In this table we classify parents by the various combinations of married and unmarried children that we have identified. The issue that concerns us is whether parents showed a preference for living with unmarried children. Overall, they showed a clear preference for residence with unmarried children, but this effect is significantly weaker among widows. Elderly married couples almost always headed their own households, and their households almost always included an unmarried child when one was available. When the only child was married, however, the situation was more complex. Elderly married men usually $(77 \%)$ maintained households separate from their married children. But about half of the elderly married women lived with a married child, and the head of household was as likely to be the parent as the child. This difference between married men and women may be due to differences in the health of their spouses. Since women were usually younger than their husbands, an older woman was more likely to have a spouse in poor health.

Elderly widows and widowers display a somewhat different pattern. Here again, when we could find only unmarried children, they almost always lived in the household of the older generation. Widows and widowers, however, were likely to move into the household of a child, when married children were the only alternative. Finally, when both unmarried and married children were available, coresidence was the norm but household headship was less certain. The widowers headed their own households, which included a child $58 \%$ of the time. Widows, however, were only slightly more likely to continue to head a household that included a child $(46.5 \%)$ than to move in with a married child $(40.3 \%)$.

In Table 10 we use the longitudinal sample in a different way to examine the relationship between household patterns and mortality and migration. This table shows the proportion of the sample who died (or migrated) in the next year by household composition at the beginning of the year. The surprising finding in this table is that parents who lived in households headed by a married child were more likely to die: While the overall probability of death was $6.3 \%, 9.9 \%$ of those living in a household headed by a married child died in the next year. The statistical significance of this finding was checked with a logistic regression that controlled for age, year, sex, and marital status. The logistic 
regression results indicate that a sample person living in the household of a married child was 2.2 times more likely to die.

We interpret these higher death rates as evidence that these parents were in poor health before they moved in with their married children. Although parents preferred to maintain independent households, some of them apparently sought assistance from their married children shortly before their deaths.

\section{Conclusions}

These data suggest that high fertility was a good strategy to provide for support in old age in nineteenth-century Europe. Late marriage and high proportions never marrying created a large pool of unmarried children who shared the households of their aging parents. Parents with more than two surviving children could be quite confident that at least one child would continue to live with them until they reached at least age 75 . This does not mean that married children were unavailable for support, they were called upon in key situations. Parents tended to live with a married child when they had fewer surviving children, when the parent was widowed, or when their health deteriorated. However, when faced with a choice between living with an unmarried child or moving into the household of a married child, most parents chose to use the support of an unmarried child to remain heads of their own household.

If the European marriage pattern worked to the benefit of parents, this was little comfort for those without children. Those who never married could seek the help of siblings or other kin, but the majority lived with nonkin or alone (See Table 3). In many cases the unmarried elderly and those without children must have been forced to rely upon the community for support. It is not surprising, therefore, that Verviers had both a municipal old age home and outdoor relief for the poor.

It remains to be determined whether the needs of the elderly actually contributed to the late marriage and high proportions unmarried in the European past. Did parents put pressure on some children not to marry so that they could continue to draw upon their support? ? $^{5}$ Oral histories collected by Tamara Hareven sometimes mention pressures placed upon a child who was selected to care for an aging parent (Hareven \& Adams, 1991). The role of children in providing old age support may help to explain the persistence of late marriage in nineteenth-century cities like Verviers. Despite the predictions of pessimists, industrialization and urbanization in nineteenth-century Europe did not lead to extremely early marriages. Since factory workers had little hope of saving enough money to buy a farm or business, and their parents had little property to bequeath them, the motivations for late marriage proposed by Hajnal do not seem to be relevant. Perhaps the support demanded by parents from adult children played a role in continuing the European marriage pattern. 


\section{Notes}

The research reported in this paper has been supported by a grant from the National Institute on Aging, PHS AG09331. The authors would also like to thank participants in the Duke Population Studies Seminar and the RAND Conference on Economic and Demographic Aspects of Intergenerational Relations, March 20-22, 1992 for their comments.

1 Compare the references to the past in Shanas $(1961$, p. 1) to those in Friis, Townsend, and Shanas $(1968$, p. 4).

2 For example, a person who enters the sample at age 61 in 1831 and is followed until age 76 in 1846 will be observed 16 times: 4 times at ages 60-64, 5 times at ages 65-69, 5 times at ages 70-74, and twice at ages 75 and older. This person would be weighted as one-fourth for ages 61 to 64 , one-fifth for ages 65 to 74 , and one-half at ages 75 and 76 . The total weight from all 16 observations would be four. In contrast, a person who was observed only at ages 61 and 62 would be assigned weights of one-half for each of those ages, but would have a total weight of only one.

3 Household headship is in part a cultural artifact of the persons who compiled the annual registers. The order of persons in the household follows a consistent pattern in which the head, usually male, and spouse are listed first, followed by their children in descending order by age, other kin, and nonkin. After a spouse's death, widows usually continue to be listed as heads of households, even when they have coresident adult sons.

4 The boundaries between households were frequently ambiguous, and sometimes a married child would be listed in the same household one year but as a separate household the next year. About $30 \%$ of newly married couples in 1844 and 1845 were listed as separate households in the same house as a parent (Alter, 1988, pp. 136-137). The boundaries between households involve an interpretation by those who compiled the registers. However, we suspect that these boundaries may have corresponded to units of taxation.

5 In nineteenth-century Belgium, parents could easily frustrate the desires of children who wished to marry against their will. The Belgian Civil Code, derived from the Napoleonic Code, made it difficult to marry without parental consent. An adult whose parent refused to sign the marriage register was required to employ a notary to "respectfully" request the parent's permission to marry.

\section{References}

Alter, G. (1984). Work and income in the family economy: Belgium, 1853 and 1891. Journal of Interdisciplinary History, 15, 255-276.

-. (1988). Family and the Female Life Course: The Women of Verviers, Belgium, 1849-1880. Madison: University of Wisconsin Press.

Anderson, M. (1971). Family Structure in Nineteenth-Century Lancashire. Cambridge: Cambridge University Press.

Belgium, Commission du travail. (1887). Réponses au questionnaire concernante le travail industrial, vol. 1; and Procés-Verbaux des séances d'enquete concernante le travail industriel, vol. 2. Brussels: A. Lesigne.

Desama, C. (1985). Population et révolution industrielle, Bibliotheque de la Faculté de Philosophie et Lettres de l'Université de Liège, Fascicule CCXLIII. Paris: Societé d'Edition "Les Belles Lettres. 
Friis, H., Townsend, P., \& Shanas, E. (1968). Old people in three industrial societies: An introduction. In E. Shanas, P. Townsend, D. Wederburn, H. Friis, P. Milhoj, \& J. Stehouwer (Eds.), Old People in Three Industrial Societies (pp. 1-17). New York: Atherton Press.

Gutmann, M. P. (1988). Toward the Modern Economy. New York: Alfred A. Knopf.

Haines, M. R. (1979). Industrial work and the family life cycle, 1889-1890. In P. Uselding (Ed.), Research in Economic History, 4, 289-356.

Hajnal, J. (1965). European marriage patterns in perspective. In D. V. Glass \& D. E. C. Eversley (Eds.), Population and History (pp. 101-143). London: Edward Arnold.

-. (1983). Two kinds of pre-industrial household formation. In Richard Wall (Ed.), Family Forms in Historic Europe (pp. 65-104). Cambridge: Cambridge University Press.

Hareven, T. K. (1982). Family Time and Industrial Time: The Relationship Between the Family and Work in a New England Industrial Community. Cambridge: Cambridge University Press.

Hareven, T. K. \& Adams, K. (October 10-13, 1991). The middle generation: Cohort comparisons in assistance to aging parents in an American community. Paper presented at the Conference on Aging and Generational Relations, Newark, Delaware.

Kobrin, F. E. (1976). The fall of household size and the rise of the primary individual in the United States. Demography $13,127-138$.

Laslett, P. (1991). A Fresh Map of Life. Cambridge, MA: Harvard University Press.

Laslett, P., with the assistance of Wall, R. (1972). Household and Family in Past Time. Cambridge: Cambridge University Press.

Leboutte, R. (1990). Perception et mésure du vieillissement durant la transition démographique. Populations Agées et Revolution Grise, Chaire Quetelet 1986, Institut de Démographie, Université Catholique de Louvain (pp. 599-618). Louvain-la-Neuve: Editions Ciaco.

Lebrun, P. (1948). L'industrie de la laine à Verviers pendant le XVIIle et le début du XIXe siécle. Liège: Bibliothèque de la faculté de philosophie et lettres de l'Université de Liège, Fascicule 114.

Rotella, E. \& Alter, G. (August 20-24, 1990). Working class debt in the late nineteenth- century. Tenth International Economic History Congres, Leuven, Belgium,.

Ruggles, S. (October 10-13, 1991). Living arrangements of the elderly in America, 1880-1980. Paper presented at the Conference on Aging and Generational Relations, Newark, Delaware.

Shanas, E. (1961). Family relationships of older people. Health Information Foundation Research Series, No. 20. New York: Health Information Foundation.

Shorter, E. (1977). The Making of the Modern Family. New York: Basic Books.

Smelser, N. J. (1959). Social Change in the Industrial Revolution: An Application of Theory to the British Cotton Industry. Chicago: University of Chicago Press.

Smith, D. S. (1979). Life course, norms, and the family system of older Americans in 1900. Journal of Family History, 4, 285-298.

Tilly, L. A. (1979). Individual lives and family strategies in the French proletariat. Journal of Family History, 4, 137-152.

Verviers, Le Centre Public d'Aide Sociale de Verviers. (1989). Des origines a nos jours.... Verviers. 
Table 1: Unweighted and Weighted Number of Observations by Age, Verviers Longitudinal Sample, $1831-1846$

\begin{tabular}{lcccc}
\hline & \multicolumn{2}{c}{ Unweighted } & \multicolumn{2}{c}{ Weighted } \\
Age & Number & Percent & Number & Percent \\
& & & & \\
$60-64$ & 1448 & 32.1 & 554 & 40.5 \\
$65-69$ & 1730 & 38.4 & 460 & 33.6 \\
$70-74$ & 911 & 20.2 & 227 & 16.6 \\
$75+$ & 416 & 09.2 & 127 & 09.3 \\
Total & 4505 & 100.0 & & 1368 \\
\hline
\end{tabular}


Table 2: Percent of Persons 55 or Older Living with Selected Types of Other Individuals, by Sex and Age, Verviers, 1831

Percent living with:

1. Spouse

2. One or more children-
a. Any child
b. Never-married child
c. Currently-married child
d. Widowed child

3. Other kin-

a. Excluding spouse/children

b. Excluding spouse, children, sons-, daughters-in-law, grandchildren

\section{Nonkin}

5. Alone

Number $(\mathbf{N})$

Percent living with:

1. Spouse

2. One or more children-
a. Any child
b. Never-married child
c. Currently-married child
d. Widowed child

3. Other kin-

a. Excluding spouse/children

b. Excluding spouse, children, sons-, daughters-in-law, grandchildren

4. Nonkin

5. Alone

Number (N)

\section{Female}

Age Age Age Age Age Age Age $\underline{55-59} \quad \underline{60-64} \quad \underline{65-69} \quad \underline{70-74} \quad \underline{75-79} \quad \underline{80-84} \quad \underline{85+}$

$\begin{array}{lllllll}57.3 & 45.7 & 39.7 & 25.7 & 18.9 & 08.2 & 07.0\end{array}$

$\begin{array}{lllllll}70.7 & 64.2 & 65.7 & 58.8 & 48.9 & 59.2 & 46.5\end{array}$

$\begin{array}{lllllll}68.3 & 56.8 & 53.9 & 40.5 & 25.6 & 30.6 & 09.3\end{array}$

$\begin{array}{lllllll}09.2 & 13.6 & 15.2 & 20.9 & 27.8 & 28.6 & 34.9\end{array}$

$\begin{array}{lllllll}01.3 & 02.8 & 04.0 & 05.4 & 04.4 & 02.0 & 04.7\end{array}$

$\begin{array}{lllllll}24.0 & 28.1 & 26.0 & 32.4 & 36.7 & 40.8 & 39.5\end{array}$

$\begin{array}{ccccccc}11.3 & 10.5 & 05.9 & 07.4 & 06.7 & 08.2 & 04.7 \\ 25.6 & 29.3 & 22.5 & 37.2 & 36.7 & 40.8 & 62.8 \\ 03.2 & 06.2 & 08.3 & 03.4 & 05.6 & 10.2 & 04.7 \\ 379 & 324 & 204 & 148 & 90 & 49 & 43\end{array}$

Male

Age Age Age Age Age Age Age $\underline{55-59} \quad \underline{60-64} \quad \underline{65-69} \quad \underline{70-74} \quad \underline{75-79} \quad \underline{80-84} \quad \underline{85+}$

$\begin{array}{lllllll}75.3 & 74.1 & 57.5 & 57.0 & 40.3 & 40.0 & 40.7\end{array}$

$\begin{array}{lllllll}72.6 & 67.3 & 58.0 & 66.9 & 47.2 & 37.1 & 40.7\end{array}$

$\begin{array}{lllllll}71.2 & 65.4 & 53.6 & 58.7 & 38.9 & 25.7 & 33.3\end{array}$

$\begin{array}{lllllll}05.3 & 06.1 & 08.2 & 14.9 & 15.3 & 05.7 & 07.4\end{array}$

$\begin{array}{lllllll}00.9 & 00.8 & 01.9 & 01.7 & 02.8 & 05.7 & 03.7\end{array}$

$\begin{array}{lllllll}19.7 & 20.5 & 22.7 & 29.8 & 27.8 & 28.6 & 25.9\end{array}$

$\begin{array}{lllllll}11.5 & 11.4 & 09.7 & 11.6 & 09.7 & 17.1 & 14.8\end{array}$

$\begin{array}{lllllll}21.8 & 25.1 & 30.9 & 24.0 & 37.5 & 34.3 & 51.9\end{array}$

$\begin{array}{lllllll}02.9 & 03.0 & 05.8 & 04.1 & 08.3 & 02.9 & 07.4\end{array}$

$\begin{array}{lllllll}340 & 263 & 207 & 121 & 72 & 35 & 27\end{array}$


Table 3: Percent of Persons 55 or Older Living with Selected Types of Other Individuals, by Sex and Marital Status, Verviers, Belgium, 1831

\section{Percent living with:}

1. Spouse

2. One or more children-
a. Any child
b. Never-married child
c. Currently-married child

d. Widowed child

Female

\section{Male}

3. Other kin-

a. Excluding spouse \&

children

b. Excluding spouse,

children, sons-,

Married Widowed

$\underline{\text { Unmarried }}$

$\underline{\text { Married }}$

Widowed

daughters-in-law, grandchildren

4. Nonkin

51.9

91.2

93.0

5. Alone

10.5

21.0

34.2

08.2

04.9

03.7

74.5

72.1

52.1

$68.4 \quad 48.3$

08.6

26.7

01.2

06.7

$02.2 \quad 04.8$

01.5

02.1

18.3

37.5

42.7

18.1

29.8

05.6

06.6

40.2

07.9

11.8

(n)

51.2

19.7

40.8

$13.4 \quad 01.3$

09.7 
Table 4: Percent of Persons 55 and Older by Type of Household, Age, and Sex, Verviers, Belgium, 1831

\begin{tabular}{|c|c|c|c|c|c|c|c|c|}
\hline & \multicolumn{8}{|c|}{ Female } \\
\hline & All & $\begin{array}{c}\text { Age } \\
55-59\end{array}$ & $\begin{array}{c}\text { Age } \\
60-64\end{array}$ & $\begin{array}{c}\text { Age } \\
65-69\end{array}$ & $\begin{array}{c}\text { Age } \\
70-74 \\
\end{array}$ & $\begin{array}{c}\text { Age } \\
75-79 \\
\end{array}$ & $\begin{array}{c}\text { Age } \\
80-84\end{array}$ & $\begin{array}{l}\text { Age } \\
85+\end{array}$ \\
\hline All & 100.0 & 100.0 & 100.0 & 100.0 & 100.0 & 100.0 & 100.0 & 100.0 \\
\hline \multicolumn{9}{|l|}{ Head- } \\
\hline no child & 20.0 & 17.9 & 19.1 & 26.0 & 18.2 & 27.8 & 16.3 & 11.6 \\
\hline child present & 52.4 & 66.2 & 54.9 & 52.0 & 45.3 & 25.6 & 32.7 & 16.3 \\
\hline \multicolumn{9}{|l|}{ Parent-- } \\
\hline married child & 07.4 & 02.1 & 06.5 & 07.8 & 08.1 & 15.6 & 18.4 & 25.6 \\
\hline \multicolumn{9}{|l|}{ Other- } \\
\hline no child & 16.0 & 11.3 & 16.4 & 08.3 & 23.0 & 23.3 & 24.5 & 41.9 \\
\hline \multirow[t]{4}{*}{ child present } & 03.1 & 02.4 & 01.9 & 03.9 & 03.4 & 06.7 & 04.1 & 04.7 \\
\hline & \multicolumn{8}{|c|}{ Male } \\
\hline & & Age & Age & Age & Age & Age & Age & Age \\
\hline & All & $\underline{55-59}$ & $\underline{60-64}$ & $\underline{65-69}$ & 70-74 & $\underline{75-79}$ & $\underline{80-84}$ & $\underline{85+}$ \\
\hline All & 100.0 & 100.0 & 100.0 & 100.0 & 100.0 & 100.0 & 100.0 & 100.0 \\
\hline \multicolumn{9}{|l|}{ Head- } \\
\hline no child & 20.9 & 18.5 & 23.2 & 21.7 & 16.5 & 25.0 & 28.6 & 22.2 \\
\hline child present & 60.7 & 70.3 & 65.0 & 52.7 & 62.0 & 41.7 & 31.4 & 40.7 \\
\hline \multicolumn{9}{|c|}{ Parent- 5d620eet8c831e73d9fa } \\
\hline unmarried child & 00.5 & 00.3 & - & 01.9 & - & - & - & - \\
\hline married child & 01.6 & 01.2 & 00.8 & 01.9 & 02.5 & 04.2 & 02.9 & - \\
\hline \multicolumn{9}{|l|}{ Other- } \\
\hline no child & 14.8 & 08.8 & 09.5 & 19.8 & 16.5 & 27.8 & 34.3 & 37.0 \\
\hline child present & 01.5 & 00.9 & 01.5 & 01.9 & 02.5 & 01.4 & 02.9 & - \\
\hline
\end{tabular}




\begin{tabular}{|c|c|c|c|c|c|}
\hline & & & Female & & \\
\hline & All & $\begin{array}{c}\text { Age } \\
60-64\end{array}$ & $\begin{array}{c}\text { Age } \\
65-69\end{array}$ & $\begin{array}{c}\text { Age } \\
70-74\end{array}$ & $\begin{array}{l}\text { Age } \\
75+\end{array}$ \\
\hline All & 100.0 & 100.0 & 100.0 & 100.0 & 100.0 \\
\hline Head- & & & & & \\
\hline no child & 26.2 & 21.7 & 26.7 & 31.0 & 35.7 \\
\hline child present & 51.4 & 53.6 & 50.1 & 52.2 & 44.9 \\
\hline Parent- & & & & & \\
\hline unmarried child & 00.9 & 01.0 & 00.5 & 01.2 & 01.9 \\
\hline married child & 06.0 & 06.4 & 07.1 & 04.3 & 03.3 \\
\hline Other- & & & & & \\
\hline no child & 13.2 & 14.7 & 12.5 & 11.1 & 12.8 \\
\hline child present & 02.2 & 02.6 & 03.1 & 00.2 & 01.4 \\
\hline & & & Male & & \\
\hline & & Age & Age & Age & Age \\
\hline & All & $\underline{60-64}$ & $\underline{65-69}$ & $\underline{70-74}$ & $\underline{75-79}$ \\
\hline All & 100.0 & 100.0 & 100.0 & 100.0 & 100.0 \\
\hline Head- & & & & & \\
\hline no child & 28.7 & 25.0 & 25.3 & 35.3 & 44.8 \\
\hline child present & 58.0 & 62.3 & 60.8 & 50.0 & 43.6 \\
\hline Parent- & & & & & \\
\hline unmarried child & 00.8 & 00.2 & 00.9 & 01.3 & 01.8 \\
\hline married child & 01.7 & 01.4 & 01.4 & 03.3 & 00.6 \\
\hline Other- $5 \mathrm{~d}=20$ & & & & & \\
\hline no child & 09.7 & 09.8 & 10.4 & 08.9 & 08.2 \\
\hline child present & 01.2 & 01.3 & 01.0 & 01.3 & 00.9 \\
\hline
\end{tabular}


Table 6: Percent of Persons Living with Children by Number of Children Identified, Verviers Longitudinal Sample, 1831-1846

Number of Children Identified

All $\quad \begin{array}{lllllll}0 & 1 & 2 & 3 & 4 & 5 & 6+\end{array}$

Female:

Any child

$\begin{array}{llllllll}0.606 & - & 0.757 & 0.797 & 0.822 & 0.910 & 0.955 & 1.000 \\ 0.523 & - & 0.524 & 0.714 & 0.768 & 0.843 & 0.955 & 1.000 \\ 0.113 & - & 0.217 & 0.156 & 0.088 & 0.183 & 0.015 & 0.108 \\ 0.032 & - & 0.016 & 0.042 & 0.051 & 0.081 & 0.072 & 0.073\end{array}$

Male:

\begin{tabular}{lllllllll} 
Any child & 0.616 & - & 0.625 & 0.760 & 0.857 & 0.881 & 0.946 & 0.974 \\
Never-married child & 0.590 & - & 0.555 & 0.739 & 0.824 & 0.828 & 0.946 & 0.974 \\
Currently-married child & 0.039 & - & 0.067 & 0.038 & 0.040 & 0.110 & 0.007 & 0.043 \\
Widowed child & 0.019 & - & 0.003 & 0.006 & 0.071 & 0.007 & 0.028 & 0.031 \\
\hline
\end{tabular}


Table 7: Percent of Persons by Type of Household, by Number of Children Identified, Sex, and Marital Status, Verviers Longitudinal Sample, 1831-1846

Number of Children Identified

All $\quad \begin{array}{lllllll}0 & 1 & 2 & 3 & 4 & 5 & 6+\end{array}$

Female, married:

\section{Head- \\ no child \\ child present \\ Parent- \\ unmarried child \\ married child \\ Other- \\ no child \\ child present}

Female, widowed:

$\begin{array}{cccccccc}27.5 & 90.2 & 19.0 & 19.2 & 15.3 & 05.0 & \overline{-} & - \\ 68.7 & - & 74.3 & 78.8 & 82.5 & 95.0 & 100.0 & 100.0 \\ 00.1 & - & - & 00.3 & - & - & - & - \\ 01.4 & - & 06.7 & 00.3 & - & - & - & - \\ & & & & & & & \\ 02.1 & 09.8 & - & 01.3 & - & - & - & - \\ 00.3 & - & - & 00.0 & 02.2 & - & - & -\end{array}$

$\begin{array}{cccccccc}21.5 & 52.3 & 19.9 & 15.6 & 15.0 & 12.2 & - & - \\ 48.9 & - & 45.4 & 55.7 & 68.6 & 68.7 & 87.2 & 96.8 \\ & & & & & & & \\ 01.9 & - & 01.6 & 03.2 & 01.5 & 05.3 & - & - \\ 11.6 & - & 22.3 & 14.4 & 04.9 & 11.0 & - & - \\ & & & & & & & \\ 11.7 & 47.7 & 04.8 & 04.4 & 05.1 & - & 10.9 & - \\ 04.4 & - & 06.0 & 06.7 & 04.9 & 02.7 & 01.8 & 03.2\end{array}$

Male, married:

$\begin{array}{cccccccc}30.6 & 95.5 & 33.4 & 24.1 & 13.6 & 15.3 & 06.0 & 03.9 \\ 66.3 & - & 60.2 & 73.3 & 82.5 & 84.7 & 94.0 & 95.4 \\ & & & & & & & \\ 00.4 & - & - & 00.4 & 01.3 & - & - & 00.7 \\ 00.5 & - & 01.5 & 00.2 & 01.3 & - & - & - \\ 01.8 & 04.5 & 04.9 & 01.7 & - & - & - & - \\ 00.3 & - & - & 00.3 & 01.3 & - & - & -\end{array}$

continued on next page... 
Table 7 , continued...

\begin{tabular}{llllllll}
\multicolumn{8}{c}{ Number of Children Identified } \\
All & 0 & 1 & 2 & 3 & 4 & 5 & $6+$
\end{tabular}

Male, widowed:

Headno child child present

Parentunmarried child married child

Otherno child 18.

$50.6-37.1$

24.3

10.8

12.4

$50.6 \quad-$

43.2

76.7

$\begin{array}{llll}63.3 & 67.8 & 100.0 & 100.0\end{array}$

$02.0 \quad-\quad-\quad-\quad-\quad 10.7 \quad 03.2 \quad-\quad-$

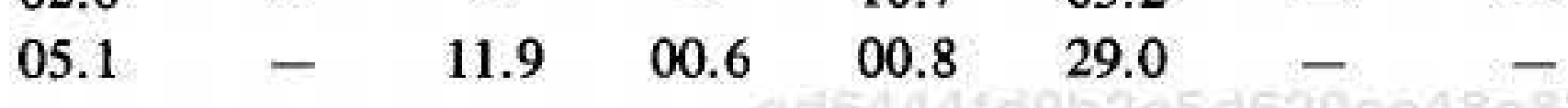

child present

20.5

62.9

11.5

08.7

03.8

03.8

09.1

03.2

09.1 
Table 8: Percent of Persons by Distance to Nearest Nonresident Child by Number of Coresident Children by Sex, Parents with at Least One Nonresident Child, Verviers Longitudinal Sample, 1831-1846

\begin{tabular}{lcccc} 
& \multicolumn{5}{c}{ Number of Coresident Children } \\
& \multicolumn{2}{c}{ Nemale } & Male \\
& None & $1^{+}$ & None & $1^{+}$ \\
Closest Coresident Child- & & & & \\
$\quad$ Same address & 13.9 & 10.6 & 13.5 & 06.4 \\
$\quad<100$ meters & 08.5 & 09.9 & 07.2 & 07.3 \\
200-500 meters & 22.8 & 17.4 & 19.1 & 14.0 \\
$500+$ meters & 04.4 & 03.4 & 02.6 & 06.6 \\
Locations unknown & 50.4 & 58.7 & 57.5 & 65.7 \\
Total & $100 \%$ & $100 \%$ & $100 \%$ & $100 \%$ \\
\hline
\end{tabular}


Types of Resident and Nonresident Children

\begin{tabular}{|c|c|c|c|c|c|c|c|c|c|}
\hline Female, married: & All & No Children & Unmarried & Married & $\begin{array}{l}\text { Unmarried } \\
\text { \& Married }\end{array}$ & Widowed & $\begin{array}{l}\text { Unmarried } \\
\text { \& Widowed }\end{array}$ & $\begin{array}{l}\text { Married \& } \\
\text { Widowed }\end{array}$ & $\begin{array}{l}\text { Locations } \\
\text { Unknown }\end{array}$ \\
\hline All & $100 \%$ & $100 \%$ & $100 \%$ & $100 \%$ & $100 \%$ & $100 \%$ & $100 \%$ & $100 \%$ & $100 \%$ \\
\hline \multicolumn{10}{|l|}{ Head- } \\
\hline no child & 27.5 & 90.2 & 01.4 & 48.0 & 06.2 & 12.5 & 04.2 & - & 95.8 \\
\hline child present & 68.7 & - & 98.6 & 24.6 & 93.0 & 87.5 & 69.8 & 100.0 & - \\
\hline \multicolumn{10}{|l|}{ Parent- } \\
\hline unmarried child & 00.1 & - & - & - & - & - & 05.2 & - & - \\
\hline married child & 01.4 & - & - & 27.4 & 00.8 & - & - & - & - \\
\hline \multicolumn{10}{|l|}{ Other- } \\
\hline no child & 02.1 & 09.8 & - & - & - & - & - & - & 04.2 \\
\hline child present & 00.3 & - & - & - & - & - & 20.8 & - & - \\
\hline
\end{tabular}

\begin{tabular}{|c|c|c|c|c|c|c|c|c|c|}
\hline Female, widowed: & All & No Children & Unmarried & Married & $\begin{array}{l}\text { Unmarried } \\
\text { \& Married }\end{array}$ & Widowed & $\begin{array}{c}\text { Unmarried } \\
\text { \& Widowed }\end{array}$ & $\begin{array}{l}\text { Marned \& } \\
\text { Widowed }\end{array}$ & $\begin{array}{l}\text { Locations } \\
\text { Unknown } \\
\end{array}$ \\
\hline All & $100 \%$ & $100 \%$ & $100 \%$ & $100 \%$ & $100 \%$ & $100 \%$ & $100 \%$ & $100 \%$ & $100 \%$ \\
\hline \multicolumn{10}{|l|}{ Head- } \\
\hline no child & 21.5 & 52.3 & 07.3 & 04.3 & 05.9 & 38.6 & - & - & 72.4 \\
\hline child present & 48.9 & - & 84.9 & 21.9 & 46.5 & 19.4 & 85.4 & 94.3 & - \\
\hline \multicolumn{10}{|l|}{ Parent- } \\
\hline unmarried child & 01.9 & - & 01.1 & - & - & 36.6 & 12.1 & - & - \\
\hline married child & 11.6 & - & - & 63.1 & 40.3 & - & - & 05.7 & - \\
\hline \multicolumn{10}{|l|}{ Other- } \\
\hline no child & 11.7 & 47.7 & 01.4 & 02.1 & - & - & - & - & 27.6 \\
\hline child present & 04.4 & - & 05.3 & 08.6 & 07.3 & 05.4 & 02.4 & - & - \\
\hline
\end{tabular}


Table 9, continued...

Types of Resident and Nonresident Children

\begin{tabular}{|c|c|c|c|c|c|c|c|c|c|}
\hline Male, married: & All & No Children & Unmarried & Married & $\begin{array}{l}\text { Unmarried } \\
\text { \& Married }\end{array}$ & Widowed & $\begin{array}{c}\text { Unmarried } \\
\& \text { Widowed }\end{array}$ & $\begin{array}{l}\text { Unmarried, } \\
\text { Married \& } \\
\text { Widowed }\end{array}$ & $\begin{array}{l}\text { Locations } \\
\text { Unknown }\end{array}$ \\
\hline All & $100 \%$ & $100 \%$ & $100 \%$ & $100 \%$ & $100 \%$ & $100 \%$ & $100 \%$ & $100 \%$ & $100 \%$ \\
\hline \multicolumn{10}{|l|}{ Head- } \\
\hline no child & 30.6 & 95.5 & 02.2 & 77.0 & 04.2 & 15.0 & 09.1 & - & 90.1 \\
\hline child present & 66.3 & - & 97.2 & 10.7 & 95.8 & 85.0 & 73.5 & 100.0 & - \\
\hline \multicolumn{10}{|l|}{ Parent- } \\
\hline married child & 00.5 & - & $\begin{array}{c}00.1 \\
-\end{array}$ & $\overline{12.4}$ & - & - & $\begin{array}{c}17.4 \\
-\end{array}$ & - & - \\
\hline \multicolumn{10}{|l|}{ Other- } \\
\hline no child & 01.8 & 04.5 & - & - & - & - & - & - & 09.9 \\
\hline child present & 00.3 & - & 00.5 & - & - & - & - & - & - \\
\hline Male, widowed: & All & No Children & Unmarried & Married & $\begin{array}{l}\text { Unmarried } \\
\& \text { Married }\end{array}$ & Widowed & $\begin{array}{c}\text { Unmarried } \\
\text { \& Widowed }\end{array}$ & $\begin{array}{l}\text { Unmarried, } \\
\text { Married \& } \\
\text { Widowed }\end{array}$ & $\begin{array}{l}\text { Locations } \\
\text { Unknown }\end{array}$ \\
\hline All & $100 \%$ & $100 \%$ & $100 \%$ & $100 \%$ & $100 \%$ & $100 \%$ & $100 \%$ & $100 \%$ & $100 \%$ \\
\hline \multicolumn{10}{|l|}{ Head- } \\
\hline no child & 18.1 & 37.1 & 02.7 & 15.8 & - & - & - & - & 61.5 \\
\hline child present & 50.6 & - & 92.8 & 10.2 & 58.0 & - & 49.8 & - & - \\
\hline \multicolumn{10}{|l|}{ Parent- } \\
\hline unmarried child & 02.0 & - & - & - & 13.9 & - & 39.5 & - & - \\
\hline married child & 05.1 & - & - & 58.0 & 17.1 & - & - & - & - \\
\hline \multicolumn{10}{|l|}{ Other- } \\
\hline no child & 20.5 & 62.9 & - & 06.9 & - & - & - & - & 38.5 \\
\hline child present & 03.8 & - & 04.5 & 09.0 & 10.9 & - & 10.7 & - & - \\
\hline
\end{tabular}


Table 10: Mortality and Migration Rates by Type of Household, Verviers Longitudinal Sample, 1831$1846(\%)$

\section{Status at End of Year}

\begin{tabular}{lcccc} 
& All & $\underline{\text { Alive }}$ & Dead & Migrate \\
All & 100.0 & 91.8 & 06.3 & 01.8 \\
$\begin{array}{l}\text { Head- } \\
\text { no child } \\
\text { child present }\end{array}$ & 100.0 & 93.1 & 06.0 & 00.9 \\
$\begin{array}{l}\text { Parent- } \\
\text { unmarried child }\end{array}$ & 100.0 & 92.5 & 06.2 & 01.3 \\
$\begin{array}{l}\text { married child } \\
\begin{array}{l}\text { Other- } \\
\text { no child }\end{array}\end{array}$ & 100.0 & 94.6 & 05.4 & - \\
child present & 100.0 & 86.8 & 09.9 & 03.3 \\
\hline
\end{tabular}

